\title{
Whole, concentrated and reconstituted grape juice: Impact of processes on phenolic composition, "foxy" aromas, organic acids, sugars and antioxidant capacity
}

\author{
Maria da Conceição Prudêncio Dutra ${ }^{\mathrm{a}}$, Arão Cardoso Viana ${ }^{\mathrm{a}}$, Giuliano Elias Pereira ${ }^{\mathrm{b}}$, \\ Rita de Cássia Mirella Resende Nassur ${ }^{\mathrm{c}}$, Marcos dos Santos Lima ${ }^{\mathrm{a} \text {,* }}$ \\ ${ }^{a}$ Instituto Federal do Sertão Pernambucano, Campus Petrolina, Departamento de Tecnologia em Alimentos, Jardim São Paulo - CEP 56314-520, Petrolina, PE, Brazil \\ ${ }^{\mathrm{b}}$ Brazilian Agricultural Research Corporation (Embrapa Semiárido/Uva e Vinho), Rodovia Br 428, Km 152, PO Box 23, CEP 56302-970 Petrolina, PE, Brazil \\ ${ }^{\mathrm{c}}$ Instituto Federal do Sertão Pernambucano, Campus Ouricuri, Departamento de Agroindústria, Estrada do Tamboril s/n, Vila Quixadá CEP 56200-000, Ouricuri, PE, \\ Brazil
}

\section{A R T I C L E I N F O}

\section{Keywords:}

Bioactive compounds

Functional beverages

Food processing

Food composition

\begin{abstract}
A B S T R A C T
The concentration and reconstitution processes of grape juices can result in losing compounds associated with beverage quality. In this context, three tanks containing 50,000 L of grape juice were individually concentrated up to $68{ }^{\circ}$ Brix using a triple vacuum concentrator. The concentrated juice was reconstituted up to the original ${ }^{\circ}$ Brix of the whole juice (18.4). Phenolic compounds, sugars and organic acids were quantified by high-performance-liquid-chromatography. "Foxy" aromatic compounds were also quantified by gas-chromatography/ mass-spectrometry. The concentration and reconstitution process resulted in significant losses (Tukey test, $\mathrm{p}<0.01$ ) of trans-caftaric acid, decreasing from 397.08 to $159.14 \mathrm{mg} / \mathrm{L}$, chlorogenic-acid from 34.97 to $8.44 \mathrm{mg} / \mathrm{L}$, aromatic furaneol compound from 9.06 to $1.93 \mathrm{mg} / \mathrm{L}$, as well as total losses for gallic-acid, caffeicacid, p-coumaric-acid, syringic-acid, hesperidin, pelargonidin-3-glucoside and epicatechin compounds. The concentration and reconstitution of grape juice preserved the antioxidant capacity and most of the quantified compounds, with the reconstituted juice having good nutritional quality.
\end{abstract}

\section{Introduction}

Grape juice consumption has mainly grown in the whole form and also reconstituted from concentrated juice. Factors such as characteristic flavor, aroma, color and refreshment have contributed to its sensory acceptance (Campos et al., 2016; Granato, de Magalhães Carrapeiro, Fogliano, \& van Ruth, 2016; Rojo et al., 2019). Another characteristic that has popularized grape juice is the 'in vitro' and 'in vivo' functional properties associated to the health of grape juice consumers, which is mainly related to phenolic compounds (Corredor et al., 2016; Granato et al., 2016; Toaldo, Cruz, Silva, \& Bordignon-Luiz, 2016; Toscano et al., 2017; Dutra, Rodrigues, Oliveira, Pereira, \& dos Santos Lima, 2018).

According to Brazilian legislation, concentrated grape juice is a product submitted to physical processes to remove water, increasing the soluble solids content present in the respective whole juice by at least $50 \%$. Reconstituted grape juice is the product obtained by diluting concentrated or dehydrated juice up to the original concentration of the fresh juice using the ${ }^{\circ}$ Brix as a parameter for reconstitution (Brazil, 2018).

Grape juices are complex matrices mainly consisting of water and several metabolites, with an emphasis on sugars, organic acids, minerals, phenolic and aromatic compounds (Capanoglu, Vos, Hall, Boyacioglu, \& Beekwilder, 2013; Lima et al., 2014; Dutra et al., 2018a, 2018b; Coelho et al., 2018; Guler, Tokusolgu, \& Artik, 2018; Li, Wei, Wang, Zhou, \& Wang, 2019).

The main Brazilian region which produces and exports grape juice is Rio Grande do Sul State in the southern region of the country. This state produced 140 million liters of whole juice and 117 million liters of concentrated juice in 2018 (Mello, 2019). The São Francisco Valley (SFV) in the Northeast of Brazil has invested heavily in grape juice production since 2012, where the main commercial juices are made by mixing the following Brazilian grapes: Isabel Precoce (Vitis labrusca) and the BRS Violeta, BRS Cora, BRS Magna, and more recently BRS

\footnotetext{
* Corresponding author.

E-mail addresses: maria.cp.dutra@gmail.com (M.d.C.P. Dutra), arao.viana@ifsertao-pe.edu.br (A.C. Viana), giuliano.pereira@embrapa.br (G.E. Pereira), rita.nassur@ifsertao-pe.edu.br (R.d.C.M.R. Nassur), marcos.santos@ifsertao-pe.edu.br (M.d.S. Lima).
} 
Carmen hybrids (Lima, M.d.S., Silani, I. S. V., Toaldo, I. M., Correa, L. C., Biasoto, A. C. T., Pereira, G. E., Ninow, J. L., Bordignon-Luiz, M. T., 2014; Dutra et al., 2018a; Padilha, dos Santos Lima, Toaldo, Pereira, \& Bordignon-Luiz, 2019). According to data collected from the producing companies in the SFV in 2019, 15 million liters of whole juice and 10 million liters for concentrated juices were prepared.

Previous studies have characterized SFV whole grape juices as high quality beverages with a high concentration of phenolic compounds, high 'in vitro'antioxidant capacity and sugars concentration, and normal acidity; presenting the oligosaccharide kestose prebiotic in its composition. The main 'foxy' aromatic compound present in SFV grape juices is Furaneol which is associated with the aromatic typicality of the juices of this region, but it is also possible to find lower amounts of methyl anthranilate and 2-aminoacetophenone. The juices can be produced in the SFV region throughout the year due to the climatic conditions of the region which enables staggered production of grapes, which in turn enables placing fresh products in the market in all periods of the year (Lima et al., 2014; Dutra et al., 2018b; Coelho et al., 2018; Padilha et al., 2019).

Several factors influence the chemical composition of juices, including processing techniques (Granato et al., 2016). Previous studies which quantified phenolic compounds and antioxidant capacity in grape juices during the processing steps highlighted a decrease in antioxidant capacity and the levels of some flavanols, phenolic acids and anthocyanins (Capanoglu et al., 2013; Guler et al., 2018). However, no other key quality components were evaluated in these previous studies such as aromas, organic acids or sugars in concentrated juices, nor the quality of reconstituted juices. In this context, the objective of the present study was to evaluate the influence of the concentration and reconstitution process on the phenolic compound, sugar and organic acid profiles by high performance liquid chromatography (HPLC), "foxy" aromatic compounds by gas chromatography/mass spectrometry (GC-MS), and the 'in vitro' antioxidant capacity of grape juices produced in the SFV region in Northeast Brazil.

\section{Material and methods}

\subsection{External standards and chemicals}

External standards for aromatic compounds and oligosaccharides: 2octanone, methyl anthranilate, 2-aminoacetophenone, 4-hydroxy-2,5dimethyl-3 $(2 \mathrm{H})$-furanone, 1-kestose, nystose and raffinose were purchased from Sigma-Aldrich (St. Louis, MO, USA). Tartaric, malic, citric, succinic and formic acids were obtained from Química Vetec (Rio de Janeiro, RJ, Brazil). TPTZ (2,3,5-Triphenyltetrazolium chloride), Trolox (6-hydroxy-2,5,7,8-tetramethylchromate-2-carboxylic acid), 2,2-diphenyl-1-picryllidrazil (DPPH), 2,2-azino-bis (3-ethylbenzothiazoline6-sulfonic acid) (ABTS), and the external standards of the phenolics: gallic acid, p-coumaric acid, chlorogenic acid, syringic acid, trans-caftaric acid, caffeic acid, hesperidin, naringenin, procyanidin $\mathrm{B} 1$, catechin, epicatechin and procyanidin B2, cyanidin-3,5-diglucoside, malvidin-3,5-diglucoside, and pelargonidin-3,5-diglucoside were purchased from Sigma-Aldrich (St. Louis, MO, USA). Acetonitrile, methanol, potassium persulfate and ethyl alcohol were obtained from Merck (Darmstadt, HE, Germany). The ultrapure water was obtained using a Marte Científica purification system (São Paulo, SP, Brazil). Procyanidin A2, epigallocatechin gallate, epicatechin gallate, kaempferol 3-glucoside, quercetin 3-rutinoside (rutin), quercetin 3-glucoside, myricetin, peonidin-3-glucoside, petunidin-3-glucoside, delphinidin-3glucoside, delphinidin-3-glucoside, malvidin-3-glucoside, cyanidin-3glucoside, pelargonidin-3-glucoside came from Extrasynthese (Genay, France). cis-Resveratrol and trans-resveratrol were obtained from Cayman Chemical Company (Ann Arbor, MI, USA).

\subsection{Grape juice processing and sampling}

The present study was carried out in the industrial grape juice production line of the Queiroz Galvão Alimentos S/A company, Timbaúba Farm, Petrolina, PE, Brazil. Batches of 50,000 L of whole grape juice were processed on three consecutive days (3 repetitions) with a blend of the following grapes: Isabel Precoce $-50 \%$, BRS Magna - $40 \%$ and BRS Carmem - 10\%. The grapes were destemmed and crushed, heated to $55{ }^{\circ} \mathrm{C}$, added with pectinase and remained in maceration for $60 \mathrm{~min}$. (depectinization). Pressing was performed and the drained juice was centrifuged, pasteurized at $85{ }^{\circ} \mathrm{C}$ for $3 \mathrm{~min}$ and then submitted to cold stabilization (tartaric stabilization) at a temperature of $2{ }^{\circ} \mathrm{C}$ for 7 days. After tartaric stabilization, the juice was drained, reheated to $25{ }^{\circ} \mathrm{C}$ and pumped into vacuum concentrating tanks, where samples named 'whole juice' were collected. The whole juice was filled in $300 \mathrm{~mL}$ glass bottles, pasteurized at $85{ }^{\circ} \mathrm{C}$ for $3 \mathrm{~min}$ and kept refrigerated $(5 \pm 1)$ until the analyzes were performed.

The respective whole juices were concentrated in a continuous set of three vacuum evaporating tanks (triple effect) of descending films at a temperature of $50{ }^{\circ} \mathrm{C}$ and pressure $\geq 600 \mathrm{~mm} \mathrm{Hg}$ until reaching 68 ${ }^{\circ} \mathrm{Brix}$ for three consecutive days (3 repetitions). Concentrated juice samples (68 ${ }^{\circ} \mathrm{Brix}$ ) were collected in $300 \mathrm{~mL}$ colorless glass bottles and kept in the refrigerator $(5 \pm 1)$ until the analyzes were performed.

The recontituted juices were obtained by diluting concentrated juices until achieving soluble solids content of $18.4{ }^{\circ}$ Brix using distiled water. After the reconstitution, the juices were filled in $300 \mathrm{~mL}$ colorless glass bottles, pasteurized at $85{ }^{\circ} \mathrm{C}$ for $3 \mathrm{~min}$., cooled and kept in a refrigerator $(5 \pm 1)$ until the analyzes were performed.

All juice elaboration processes were carried out in August 2019 and all chemical analyzes were performed in September 2019. The treatments were named whole grape juice (WGJ), concentrated grape juice (CGJ) and reconstituted grape juice (RGJ), manufactured in industrial conditions and processed in three independent batches (3 repetitions).

\subsection{Quality analysis - classic parameters and color}

The $\mathrm{pH}$ was measured in a PHS-3B digital bench potentiometer (Tecnal, Brazil), soluble solids (SS) in ${ }^{\circ}$ Brix, analyzed using a HI 96,801 digital refractometer (Hanna, United States), titratable acidity (AT) by titulometry, and color and hue (tone) intensity by the absorbances 420 , 520 and $620 \mathrm{~nm}$ in a UV 2000A UV-Visible spectrophotometer (Instrutherm, Brazil) using glass cuvettes with $0.2 \mathrm{~cm}$ of optical path, all following the methodology described by the International Organization of Grape and Wine - OIV (2011).

\subsection{In vitro antioxidant capacity by spectrophotometry}

The in vitro antioxidant capacity was evaluated using the Ferric reducing antioxidant power (FRAP) (Rufino et al., 2006), Hydrogen peroxide scavenging activity $\left(\mathrm{H}_{2} \mathrm{O}_{2}\right)$ (Ruch, Cheng, \& Klaunig, 1989), and free radical scavenging by DPPH (1,1-diphenyl-2-picrylhydrazyl) and ABTS 2,2-azinobis-(3-ethylbenzthiazoline-6-sulfonic acid) techniques following the methodologies described by Kim, Guo, and Packer (2002) and Re et al. (1999), respectively. Analytical standard Trolox was used to construct the calibration curves except for the FRAP method, in which ferrous sulphate was used. The results were expressed as Trolox equivalents per liter of grape juice $\left(\mathrm{mmol} \mathrm{TE}^{-1}\right)$ and $\mathrm{mmol}$ of $\mathrm{Fe}^{2+}$ per liter of grape juice ( $\mathrm{mmol} \mathrm{Fe} \mathrm{L}^{2+} \mathrm{L}^{-1}$ ).

The FRAP reagent was prepared in $300 \mathrm{mmol} \mathrm{L}^{-1}$ acetate buffer $(\mathrm{pH}$ 3.6), $10 \mathrm{mmol} \mathrm{L}^{-1} \mathrm{TPTZ}$ (2,4,6-tris(2-pyridyl)-s-triazine) in a $40 \mathrm{mmol} \mathrm{L}$ ${ }^{1} \mathrm{HCl}$ and $20 \mathrm{mmol} \mathrm{FeCl}_{3}$ solution. The grape juice $(90 \mu \mathrm{L})$ and $270 \mu \mathrm{L}$ of ultrapure water were mixed with $2.7 \mathrm{~mL}$ of FRAP reagent. They were subsequently mixed in a tube and incubated for $30 \mathrm{~min}$ in a thermodigester block (Bioplus IT-2002, Barueri, SP, Brazil). The absorbance was measured at $595 \mathrm{~nm}$.

$\mathrm{H}_{2} \mathrm{O}_{2}$ method: a hydrogen peroxide solution ( $4 \mathrm{mmol}$ ) was prepared 
in phosphate buffer ( $\mathrm{pH} 7.4)$. The juice samples $(0.4 \mathrm{~mL})$ were mixed with hydrogen peroxide solution $(0.6 \mathrm{~mL})$ with the final volume adjusted to $3 \mathrm{~mL}$ using the phosphate buffer. The absorbances were spectrophotometrically determined at $230 \mathrm{~nm}$ after $10 \mathrm{~min}$. Phosphate buffer was used as the blank sample.

The $\mathrm{ABTS}^{*+}$ radical was formed by the reaction of the $7 \mathrm{mmol}$ ABTS solution with $140 \mathrm{mmol}$ potassium persulfate incubated at $25{ }^{\circ} \mathrm{C}$ without light incidence for $16 \mathrm{~h}$. The radical was diluted in ethanol to the absorbance of $0.70 \pm 0.05$ at $734 \mathrm{~nm}$. Next, a $300 \mu \mathrm{L}$ aliquot of the sample was transferred to $2700 \mu \mathrm{L}$ of the radical and the readings were carried out $6 \mathrm{~min}$ after adding the sample in a dark environment.

A DPPH solution ( $1 \mathrm{mmol} \mathrm{L}^{-1}$ ) was prepared in absolute ethanol and diluted to an absorbance of $0.900 \pm 0.050\left(100 \mu \mathrm{mol} \mathrm{L}^{-1}\right)$. The antioxidant capacity of the samples was assessed through the decay rate in absorbance at $517 \mathrm{~nm}$. The absorbance of free radical solution was determined before and after adding juice samples. The absorbance was measured at time $\mathrm{t}=30 \mathrm{~min}$ after adding the grape juice. All absorbance readings were performed using a UV-Vis 2000A spectrophotometer (Instrutherm, Brazil).

\subsection{Determination of phenolic compouds, organic acids, sugars and} oligosaccharides by HPLC

All analyses by high performance liquid chromatography (HPLC) were performed using an Agilent 1260 Infinity LC chromatography system (Agilent Technologies, Santa Clara - USA) coupled to a refractive index detector (RID) (model G1362A) and a diode array detector (DAD) (model G1315D). The data were processed using OpenLAB CDS ChemStation Edition software (Agilent Technologies, Santa Clara USA).

The individual phenolic profile was determined in HPLC/DAD according to the method validated by Padilha et al. (2017) with adaptations by Dutra et al. (2018). The column used was Zorbax Eclipse Plus RP-C18 $(100 \times 4.6 \mathrm{~mm}, 3.5 \mu \mathrm{m})$ with a Zorbax C18 $(12.6 \times 4.6 \mathrm{~mm}$, $5 \mu \mathrm{m}$ ) (Zorbax, USA) pre-column. The oven temperature was maintained at $35{ }^{\circ} \mathrm{C}$ and the injection volume was $20 \mu \mathrm{L}$ of the sample, previously diluted in phase A and filtered through a $0.45 \mu \mathrm{m}$ membrane (MillexMillipore, Barueri, SP, Brazil). The solvent flow was $0.8 \mathrm{~mL} \mathrm{~min}{ }^{-1}$. The gradient used in the separation was $0-5 \mathrm{~min}: 5 \% \mathrm{~B}$; 5-14 min: $23 \% \mathrm{~B} ; 14-30 \mathrm{~min}: 50 \% \mathrm{~B} ; 30-33 \mathrm{~min}: 80 \% \mathrm{~B}$, in which solvent $\mathrm{A}$ is a phosphoric acid solution ( $\mathrm{pH} 2.0$ ) and solvent $\mathrm{B}$ is methanol acidified with $\mathrm{H}_{3} \mathrm{PO}_{4} 0.5 \%$. Compound detection occurred by comparison with the external standards. All quantified phenolics showed calibration curves with $\mathrm{R}^{2}>0.998$. The detection and quantification limits (LOD \& LOQ, respectively) for all analyzed compounds were LOD $<0.17 \mathrm{mg} \mathrm{L}^{-1}$ and LOQ $<1.41 \mathrm{mg} \mathrm{L}^{-1}$. The spectral purity of the peaks was assessed by the threshold test (purity factor $>990$ ) in order to ensure that there was no coelution in the quantified peaks, following the methodology of Padilha et al. (2017). The chromatogram obtained from the mixture of the phenolic compounds external standards is shown in Fig. Supplementary figure 1 in the supplementary material.

Sugar and organic acids were simultaneously determined in HPLCDAD/RID using the methodology validated by Coelho et al. (2018). An Agilent Hi-Plex H ion exchange column $(300 \times 7.7 \mathrm{~mm})$ with internal particles of $8.0 \mu \mathrm{m}$ was used and protected by a PL Hi-Plex H precolumn $(5 \times 3 \mathrm{~mm})$ (Agilent Technologies, Santa Clara, CA, USA). The column oven temperature was maintained at $70{ }^{\circ} \mathrm{C}$. The sample volume injected was $10 \mu \mathrm{L}$ and the solvent flow was $0.6 \mathrm{~mL} \mathrm{~min}^{-1}$. The mobile phase was a $4 \mathrm{mmol} \mathrm{L}^{-1} \mathrm{H}_{2} \mathrm{SO}_{4}$ solution. The grape juice was previously diluted in ultrapure water, filtered through a $0.45 \mu \mathrm{m}$ nylon membrane (MillexMillipore, Barueri, SP, Brazil) and injected. Organic acids were detected in a DAD $(210 \mathrm{~nm})$, and sugars using a RID. All quantified sugars and acids showed calibration curves with $\mathrm{R}^{2}>0.997$. The limits of detection and quantification for all evaluated compounds were LOD $<0.044 \mathrm{~g} \mathrm{~L}^{-1}$ and LOQ $<0.151 \mathrm{~g} \mathrm{~L}^{-1}$, respectively.
The prebiotic oligosaccharides 1-kestose, nystose and raffinose in HPLC/RID followed the method validated by Lima (2019). The grape juice samples were filtered through a $0.45 \mu \mathrm{m}$ nylon membrane and the volume of $20 \mu \mathrm{L}$ was injected. The separation took place on a Synergi ${ }^{\mathrm{TM}}$ Hydro-RP C18 column with polar endcapping $(150 \times 4.6 \mathrm{~mm}, 4 \mu \mathrm{m})$ (Phenomenex, Torrance, CA, USA) at $35^{\circ} \mathrm{C}$. The solvent flow used was $0.7 \mathrm{~mL}$. The gradient used was 0-8 min: $100 \% \mathrm{~A}$; 8-9 min: $80 \% \mathrm{~B}$; 9-12 min: 80\% B; 12-13 min: 100\% A; 13-20 min: 100\% A (flowrate of $1.5 \mathrm{~mL} \mathrm{~min}^{-1}$ ); in which solvent A was ultrapure water and solvent $B$ was acetonitrile. The detection of oligosaccharides occurred in the RID. The detection and quantification limits for all analyzed compounds were LOD $<0.042 \mathrm{~g} \mathrm{~L}^{-1}$ and LOQ $<0.109 \mathrm{~g} \mathrm{~L}^{-1}$, respectively. All quantified sugars and acids showed calibration curves with $\mathrm{R}^{2}>0.998$.

Chromatograms representing the analysis of phenolic compounds, sugars, organic acids, and oligosaccharides in the whole juice are shown in Figs. Supplementary figure 2, 3 and 4, respectively.

\subsection{Determining the "Foxy" aromatic compounds by GC-MS}

Determination of the "Foxy" aromatic compounds Methyl anthranilate (MA), Furaneol and 2-Aminoacetophenone (2-AAP) were performed following the method validated by Dutra et al. (2018b). The aromatic compounds were extracted using the liquid-liquid method (LLE) with ethyl acetate as the organic phase. Three grams of anhydrous sodium sulfate and $1 \mathrm{~mL}$ of the internal standard (2-octanone at $44.8 \mathrm{mg} \mathrm{L}^{-1}$ ) were added to $50 \mathrm{~mL}$ of grape juice. Three successive vortex extractions were performed with 8,2 and $2 \mathrm{~mL}$ of ethyl acetate, respectively, during $5 \mathrm{~min}$. The organic phases of the three extractions were mixed and centrifuged at 3000 turns for a period of $2 \mathrm{~min}$. The supernatant was filtered through a $0.22 \mu \mathrm{m}$ porosity Nylon membrane (Millex Millipore, Barueri, SP, Brazil).

The analyzes were performed using an Agilent Technologies model 7820A gas-chromatograph system (GC) coupled to an Agilent Technologies model 5977E MSD selective mass detector (MS) using split mode with a $30: 1$ ratio and $15 \mathrm{~mL} / \mathrm{min}$ flow division at $200{ }^{\circ} \mathrm{C}$.. A CP-WAX $52 \mathrm{CB}$ capillary column $(30 \mathrm{~m} \times 0.25 \mathrm{~mm} \times 0.25 \mu \mathrm{m})$ (Varian, Lake Forest, CA, USA) with a flow rate of $0.5 \mathrm{~mL} / \mathrm{min}$ was used. The oven temperature was $60^{\circ} \mathrm{C}(1 \mathrm{~min})$, heating at $10^{\circ} \mathrm{C} / \mathrm{min}$. up to $200{ }^{\circ} \mathrm{C}$ (5 min.) and maximum oven temperature of $220{ }^{\circ} \mathrm{C}$. The temperature was maintained at $200{ }^{\circ} \mathrm{C}$ and the mobile phase was Helium gas with a purity of 5.0. The analysis was carried out in SIM mode, in which the specific ions sought for furaneol were $(\mathrm{m} / \mathrm{z}) 43,57$ and 128; 2-AAP $(m / z) 92,120,135,136$; and MA $(m / z) 92,119$ and 151. Next, $1 \mu \mathrm{L}$ of the sample was injected and the identification was compared with the retention time of external standards and confirmation by specific ions. Data acquisition and processing was performed using Mass Hunter Agilent TechnologiesTM Software (Santa Clara, CA, USA). A typical chromatogram for the analysis of aromatic compounds in whole grape juice is shown in the Fig. Supplementary figure 5.

\subsection{Statistical analysis}

The results obtained were submitted to variance analysis (one-way ANOVA) and compared by the Tukey test at $1 \%$ of error probability. Principal component analysis (PCA) was also performed using the SPSS Version 20.0 statistical package for Windows (SPSS, Chicago, USA).

\section{Results and discussion}

\subsection{Basic quality analysis, sugars, organic acids and oligosaccharides}

The results obtained for basic quality analyzes are shown in Table 1. The average $\mathrm{pH}$ values were $3.01,3.06$ and 3.36 in concentrated (CGJ), reconstituted (RGJ) and whole (WGJ) grape juices, respectively. The concentration process resulted in an increase in the soluble solids 
Table 1

Classic analysis, sugar and organic acids from whole, concentrated and reconstituted grape juices.

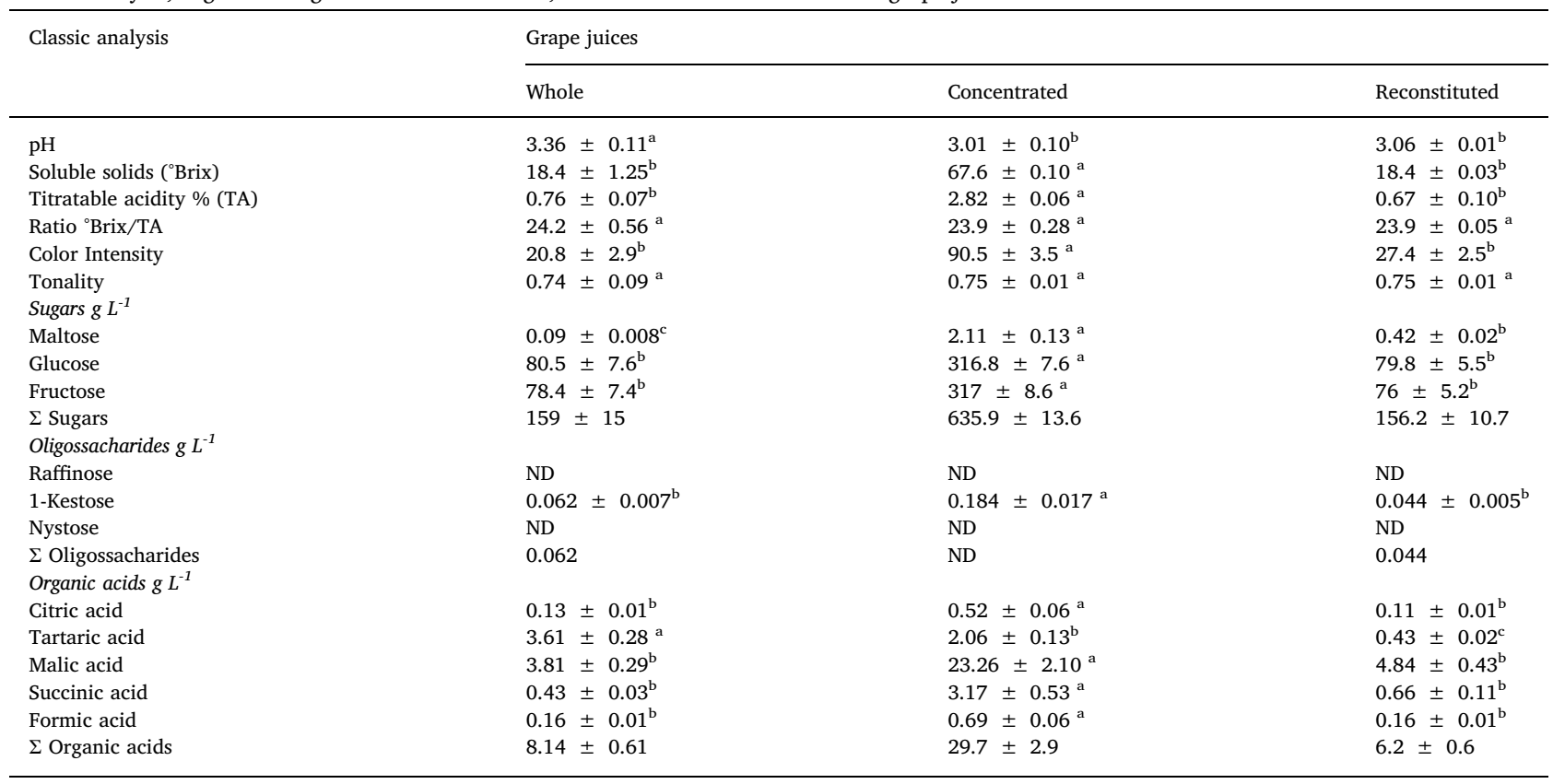

The results are expressed as mean \pm standard deviation $(n=3)$. Means followed by the same latter in lines are not different among themselves by the Tukeýs test at $1 \%$ of error probability. ND = not detected.

content ( ${ }^{\circ}$ Brix) from 18.4 to $67.6{ }^{\circ}$ Brix during the whole juice concentration, with the cited results being in accordance to Brazilian legislation, which establishes a minimum of $14^{\circ}$ Brix for whole grape juice, and a minimum increase of $50 \%$ in the soluble solids content in the respective concentrated juice (Brazil, 2018). The titratable acidity values were $0.76 \%$ in whole juice, $0.69 \%$ in reconstituted and $2.82 \%$ in concentrated juice. There was no significant difference between WGJ and RGJ juices regarding ${ }^{\circ}$ Brix, titratable acidity and color according to the Tukey test at $1 \%$ of error probability. These results are in accordance with those described by other authors for commercial grape juices from the SFV (Coelho et al., 2018; Lima, 2015; Padilha et al., 2017). The main differences observed in ${ }^{\circ}$ Brix, titratable acidity and color were for the CGJ, which was already expected due to the water removal in the concentration process, increasing the content of soluble solids such as sugars, organic acids and other compounds related to color (Aguiar, Miranda, Gomes, Santos, \& de Freitas, 2012). These results demonstrate that the reconstituted juice did not differ significantly from the whole juice in basic physico-chemical characteristics, and that the concentration process preserved the color of the juice after reconstitution.

The final soluble solids content ( ${ }^{\circ}$ Brix) and color maintainance in concentrated juices mainly depends on the production technique and process conditions such as temperature and pressure applied to the vacuum concentrators; however, it is recommended to achieve ${ }^{\circ}$ Brix $\geq 65$, (usually $68^{\circ} \mathrm{Brix}$ ) to guarantee the microbiological stability of the product during storage at room temperature (Capanoglu et al., 2013; Gollück, Souza, \& Tavares, 2008; Guler et al., 2018). In addition to the classic technique of concentrating juices by heating combined with the use of vacuum, other techniques of removing water without using heating such as reverse osmosis membranes, osmotic evaporation and crioconcentration have also been used. However, $65^{\circ} \mathrm{Brix}$ is not always reached for preservation at room temperature (Aguiar et al., 2012; Aider \& Halleux, 2008; Couto, Cabral, Da Mata, Deliza, \& Freitas, 2011; Gunathilake, Yu, \& Rupasinghe, 2014).

The averages of total quantified sugars were $156.2 \mathrm{~g} \mathrm{~L}^{-1}, 159 \mathrm{~g} \mathrm{~L}^{-1}$ and $635.9 \mathrm{~g} \mathrm{~kg}^{-1}$ in RGJ, WGJ and CGJ samples, respectively (Table 1). The main sugars present in the evaluated samples were glucose and fructose, with values of 80.5 and $78.4 \mathrm{~g} \mathrm{~L}^{-1}$ (WGJ), and 79.8 and $76 \mathrm{~g} \mathrm{~L}^{-1}$ (RGJ), respectively. The glucose and fructose levels increased to 316.8 and $317 \mathrm{~g} \mathrm{~kg}^{-1}$ from the concentration process in the CGJ sample, respectively. Maltose was also present in smaller amounts. There was no significant difference between the glucose and fructose levels in the WGJ and RCJ juices, but these results were already expected since these monosaccharides do not suffer degradation in the concentration process temperature $\left(50{ }^{\circ} \mathrm{C}\right)$. Maltose presented a significant loss from WGJ juice to RCJ, which may suggest an eventual hydrolysis of this disaccharide. The glucose, fructose and maltose values are in accordance with those obtained in other studies on the composition of whole grape juices from the SFV (Coelho et al., 2018; Padilha et al., 2019).

The quantified amount of organic acids was $8.14 \mathrm{~g} \mathrm{~L}^{-1}$ in WGJ juice, $6.20 \mathrm{~g} \mathrm{~L}^{-1}$ in RGJ juice and $29.70 \mathrm{~g} \mathrm{~kg}^{-1}$ in CGJ juice (Table 1). These results are similar to those presented in other studies with whole grape juice from the SFV region (Coelho et al., 2018; Lima et al., 2014). The main acids present in the juices were tartaric and malic in values of 3.61 and $3.81 \mathrm{~g} \mathrm{~L}^{-1}$, respectively, in WGJ juice. The Tukey test $(\mathrm{p}<0.01)$ showed a significant difference between the WGJ and RGJ juices only for tartaric acid, where the values were 3.61 and $0.43 \mathrm{~g} \mathrm{~L}^{-1}$ respectively, resulting in a decrease of $88.1 \%$ for the mean value. The amounts of citric, succinic and formic acids did not significantly differ when comparing WGJ and RGJ juices.

The decrease in the tartaric acid content in WGJ juice for RGJ may be associated with insolubilization of tartaric acid in the form of potassium bitartrate crystals during the concentration process (Li et al., 2019). Sugars and organic acids are related to the taste balance of grape juices (Coelho et al., 2018), and there was generally no significant difference in the studied juices regarding these substances when comparing whole and reconstituted juice, except for tartaric acid which decreased.

Regarding prebiotic oligosaccharides, raffinose and nystose were not detected, but 1-kestose was present in values of $0.062 \mathrm{~g} \mathrm{~L}^{-1}$, $0.184 \mathrm{~g} \mathrm{~kg}^{-1}$ and $0.044 \mathrm{~g} \mathrm{~L}^{-1}$ in the WGJ, CGJ and RGJ samples, respectively (Table 1 ). Accordng to the Tukey test ( $<<0.01$ ), there was no significant difference in the 1-kestose contents between the WGJ and RGJ juices, which shows that the concentration process could preserve 
Table 2

Phenolic composition of whole, concentrated and reconstituted grape juices at the São Francisco Valley, Northeast Brazil.

\begin{tabular}{|c|c|c|c|}
\hline \multirow{2}{*}{$\begin{array}{l}\text { Phenolic compounds mg } \\
\mathrm{L}^{-1}\end{array}$} & \multicolumn{3}{|l|}{ Grape juices } \\
\hline & Whole & Concentrated & Reconstituted \\
\hline \multicolumn{4}{|l|}{ Flavanols } \\
\hline Catechin & $27.78 \pm 4.38^{b}$ & $104.7 \pm 8.5^{\mathrm{a}}$ & $20.76 \pm 2.89^{\mathrm{b}}$ \\
\hline Epicatechin & $1.17 \pm 0.83$ & ND & ND \\
\hline Epicatechin gallate & $1.12 \pm 0.3$ & ND & ND \\
\hline Epigallocatechin gallate & $5.07 \pm 3.54$ & ND & $\mathrm{ND}$ \\
\hline Procyanidin A2 & $2.88 \pm 0.2^{\mathrm{b}}$ & $5.6 \pm 0.5^{\mathrm{a}}$ & $2.5 \pm 1.1^{\mathrm{b}}$ \\
\hline Procyanidin B1 & $12.17 \pm 0.45^{\mathrm{b}}$ & $30.75 \pm 3.49^{\mathrm{a}}$ & $6.40 \pm 0.59^{c}$ \\
\hline Procyanidin B2 & $28.03 \pm 2.29^{b}$ & $107.9 \pm 7.6^{\mathrm{a}}$ & $21.42 \pm 2.9^{b}$ \\
\hline \multicolumn{4}{|l|}{ Flavonols } \\
\hline Quercetin 3-glucoside & $9.24 \pm 3.7^{\mathrm{b}}$ & $19.2 \pm 5.1^{\mathrm{a}}$ & $3.96 \pm 1.1^{\mathrm{b}}$ \\
\hline Rutin & $0.69 \pm 0.49^{b}$ & $3.22 \pm 0.5^{\mathrm{a}}$ & $0.67 \pm 0.1^{\mathrm{b}}$ \\
\hline Kaempferol 3-glucoside & $3.45 \pm 0.6^{\mathrm{b}}$ & $15.13 \pm 1.1^{\mathrm{a}}$ & $3.15 \pm 0.2^{\mathrm{b}}$ \\
\hline Myricetin & $53.17 \pm 2.8^{\mathrm{b}}$ & $279.5 \pm 19.4^{\mathrm{a}}$ & $52.6 \pm 4.3^{\mathrm{b}}$ \\
\hline \multicolumn{4}{|l|}{ Anthocyanins } \\
\hline Cyanidin 3,5-diglucoside & $7.82 \pm 2.1^{\mathrm{b}}$ & $30.1 \pm 1.7^{\mathrm{a}}$ & $6.9 \pm 1.5^{\mathrm{b}}$ \\
\hline Delphinidin 3-glucoside & $11.7 \pm 3.2^{\mathrm{b}}$ & $46.3 \pm 2.2^{\mathrm{a}}$ & $10.55 \pm 1.4^{\mathrm{b}}$ \\
\hline Malvidin 3,5-diglucoside & $89.7 \pm 6.4^{b}$ & $433.3 \pm 22^{\mathrm{a}}$ & $81.1 \pm 10^{\mathrm{b}}$ \\
\hline Cyanidin 3-glucoside & $5.6 \pm 1.4^{\mathrm{b}}$ & $24.6 \pm 3.6^{\mathrm{a}}$ & $5.0 \pm 0.8^{\mathrm{b}}$ \\
\hline Peonidin 3-glucoside & $9.33 \pm 1.1^{\mathrm{b}}$ & $35.32 \pm 5.5^{\mathrm{a}}$ & $7.35 \pm 1.2^{\mathrm{b}}$ \\
\hline Malvidin 3-glucoside & $52.6 \pm 6.6^{\mathrm{b}}$ & $200.7 \pm 12.2^{\mathrm{a}}$ & $44.64 \pm 6.9^{b}$ \\
\hline Petunidin 3-glucoside & $88.1 \pm 10^{\mathrm{b}}$ & $346 \pm 11^{\mathrm{a}}$ & $79.1 \pm 10.7^{b}$ \\
\hline $\begin{array}{l}\text { Pelargonidin } 3,5- \\
\text { diglucoside }\end{array}$ & ND & ND & ND \\
\hline Pelargonidin 3-glucoside & $2.23 \pm 1.1$ & ND & ND \\
\hline \multicolumn{4}{|l|}{ Stilbenes } \\
\hline cis-Resveratrol & $8.32 \pm 0.8^{b}$ & $57.7 \pm 2.1^{\mathrm{a}}$ & $5.63 \pm 0.73^{b}$ \\
\hline trans-Resveratrol & $1.17 \pm 0.07^{\mathrm{b}}$ & $3.50 \pm 0.5^{\mathrm{b}}$ & $0.73 \pm 0.1^{\mathrm{b}}$ \\
\hline \multicolumn{4}{|l|}{ Flavanones } \\
\hline Hesperidin & $4.03 \pm 1.3$ & ND & ND \\
\hline Naringenin & $3.53 \pm 0.79^{\mathrm{b}}$ & $5.17 \pm 1.04^{\mathrm{a}}$ & $2.01 \pm 0.86^{\mathrm{b}}$ \\
\hline \multicolumn{4}{|l|}{ Phenolic acids } \\
\hline Gallic acid & $11.51 \pm 1.26$ & ND & ND \\
\hline Syringic acid & $6.05 \pm 1.73$ & ND & ND \\
\hline trans-Caftaric acid & $397.08 \pm 71.4^{b}$ & $707.7 \pm 94^{\mathrm{a}}$ & $159.14 \pm 26^{c}$ \\
\hline Chlorogenic acid & $34.97 \pm 9.1^{\mathrm{a}}$ & $34.28 \pm 7^{\mathrm{a}}$ & $8.44 \pm 3.4^{\mathrm{b}}$ \\
\hline Caffeic acid & $17.5 \pm 5.3$ & ND & ND \\
\hline$p$-Coumaric acid & $10.15 \pm 4.1$ & ND & ND \\
\hline
\end{tabular}

The results are expressed as mean \pm standard deviation $(n=3)$. Means followed by the same letter in the line are not different according to Tukeýs test at $1 \%$ of error probability.

this important prebiotic. In a study performed by Lima, M.d.S., Nunes, P.C., Silva, B.L.A., Padilha, C.V.S., Bonfim, T. H. F., Stamford, T.L.M., Vasconcelos, M.A.S., Aquino, J.S. (2019), 1-kestose was reported in commercial grape juices from the SFV, where it was observed that this prebiotic oligosaccharide (even in small amounts) together with phenolic compounds in the grape may have a possible synergistic effect for consumers regarding their intestinal health.

\subsection{Profile of phenolic compounds and 'in vitro' antioxidant capacity}

The phenolic composition of the studied juices is shown in Table 2. A total of 29 phenolic compounds were quantified by HPLC, with 7 flavanols, 4 flavonols, 8 anthocyanins, 2 stilbenes, 2 flavanones and 6 phenolic acids.

\subsubsection{Flavanols and flavonols}

Within the flavanols in the evaluated juice samples presented in Table 2, the highest amounts were observed for procyanidin B2, catechin and procyanidin $\mathrm{B} 1$, whose values in the whole juice (WGJ) were 28.03, 27.78 and $12.17 \mathrm{mg} \mathrm{L}^{-1}$ respectively. The concentration process increased the content of these flavanols, in which the values of procyanidin B1, catechin and procyanidin B2 in the CGJ juice were 107.9, 104.7 and $30.75 \mathrm{mg} \mathrm{kg}^{-1}$, respectively. No significant differences for catechin, procyanidin $\mathrm{B} 2$ and procyanidin A2 were observed between the WGJ and RGJ juices according to the Tukey test ( $p<0.01$ ). Signifficant differences were only observed for the procyanidin B1 compound, with lower values observed in the RGJ sample $\left(6.4 \mathrm{mg} \mathrm{L}^{-1}\right)$. The epicatechin, epicatechin gallate and epigallocatechin gallate flavanoids were only present in the whole juice, being lost in the concentration process.

In a study performed by Guler et al. (2018), the composition of phenolic acids and four flavanols in grape juices were analyzed during their processing steps from pressing to concentration at $45{ }^{\circ} \mathrm{Brix}$ at an evaporation temperature of $50{ }^{\circ} \mathrm{C}$ and $600 \mathrm{~mm} \mathrm{Hg}$ vacum. The authors did not observe significant difference for catechin, epicatechin or epigallocatechin between the whole and concentrated grape juice. However, if we consider the amount of water removed during concentration and subsequent reconstitution until the achievement of the ${ }^{\circ}$ Brix of the whole juice, there was a considerable loss of these flavanols in the concentration process.

Mirycetin was the main compound present regarding flavonols in terms of quantity, with average values of $57.17 \mathrm{mg} \mathrm{L}^{-1}$ in WGJ juice, $279.5 \mathrm{mg} \mathrm{kg}^{-1}$ in CGJ and RGJ $52.6 \mathrm{mg} \mathrm{L}^{-1}$. Quercetin 3-glucoside showed values of $9.24 \mathrm{mg} \mathrm{L}^{-1}, 19.3 \mathrm{mg} \mathrm{kg}^{-1}$ and $3.96 \mathrm{mg} \mathrm{L}^{-1}$ in WGJ, CGJ and RGJ juices, respectively. Grape juices also presented kaempferol 3-glucoside and rutin in their composition, but in lower amounts. The concentration process did not affect the quantified flavonols as

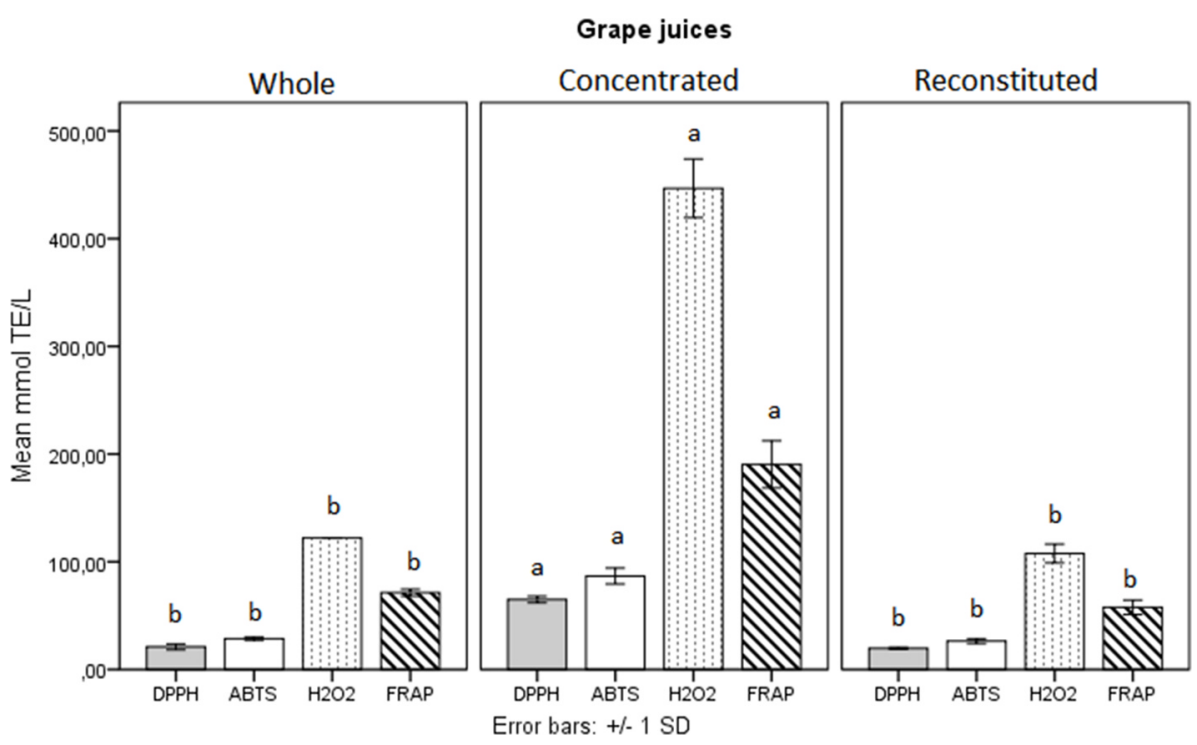

Fig. 1. In vitro antioxidant activity of whole, concentrated, and reconstituted grape juices. Legend: DPPH, ABTS e $\mathrm{H}_{2} \mathrm{O}_{2}=$ antioxidant capacity equivalent to mmol Trolox per litre of grape juice. FRAP = antioxidant capacity equivalent to $\mathrm{mmol}$ $\mathrm{Fe}^{2+}$ per litre of grape juice. Means in the bars followed by the same letters among samples are not different according to the Tukeýs test at $1 \%$ of error probability. 
Grape juices

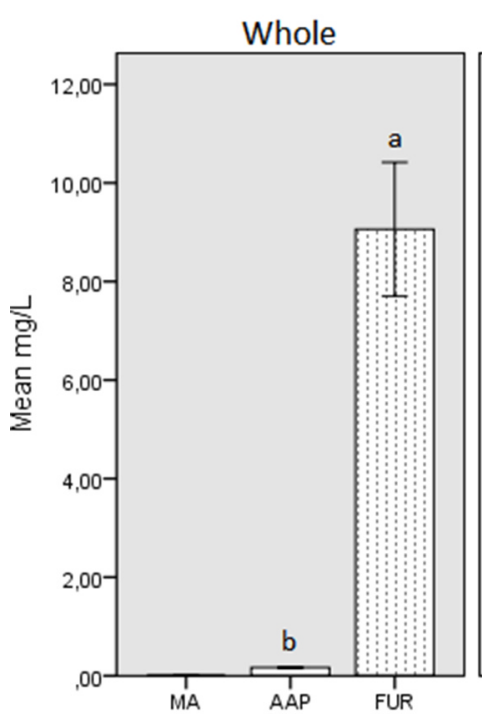

Concentrated

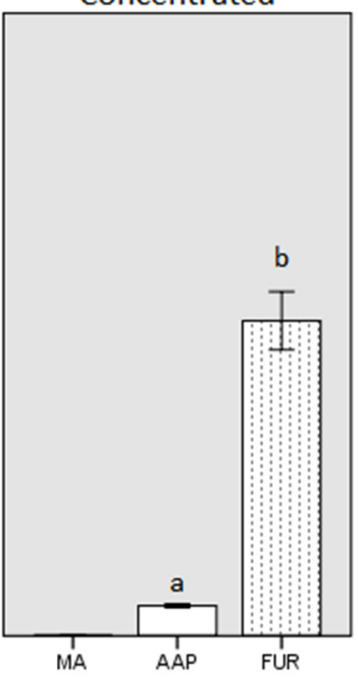

Error bars: +/- $1 \mathrm{SD}$

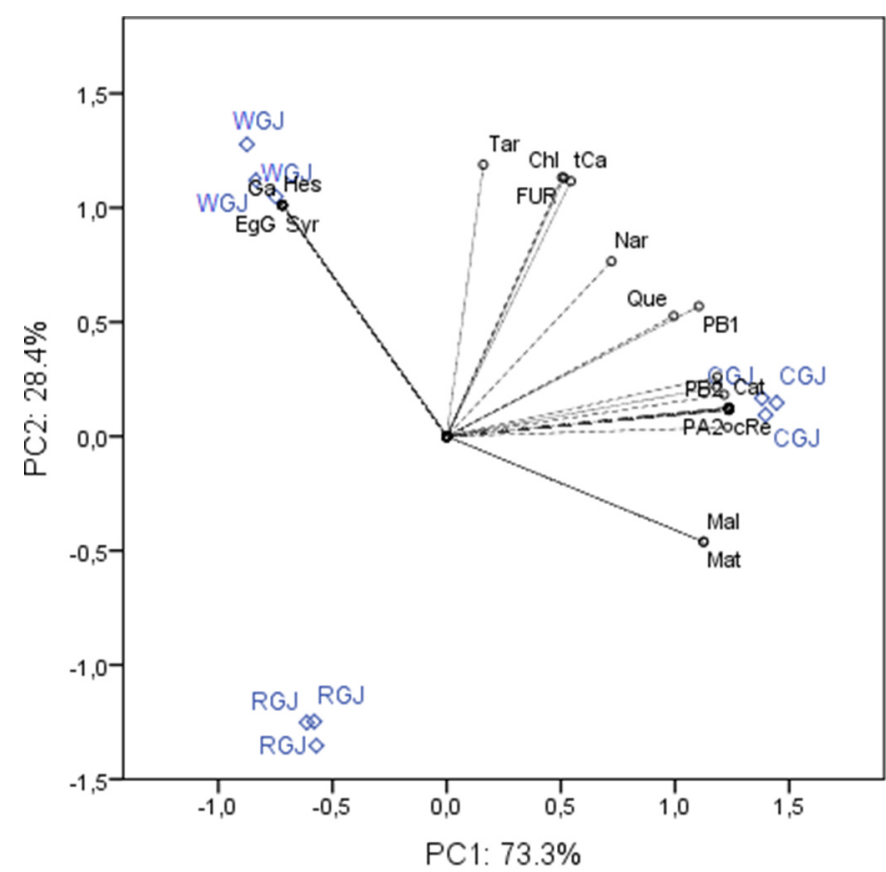

Variable Principal Normalization

there was no significant difference between the values found in the WGJ and RGJ samples.

\subsubsection{Anthocyanins}

Nine anthocyanins were quantified in grape juices and are shown in Table 2, where pelargonidin 3,5-diglucoside was the only one not detected. The main anthocyanins found in whole grape juice with highest amounts were malvidin 3,5-diglucoside $\left(89.7 \mathrm{mg} \mathrm{L}^{-1}\right)$, petunidin 3glucoside $\left(88.1 \mathrm{mg} \mathrm{L}^{-1}\right)$ and malvidin 3-glucoside $\left(52.5 \mathrm{mg} \mathrm{L}^{-1}\right)$. However, the following compounds were also detected in lower amounts: delphinidin 3-glucoside $\left(11.7 \mathrm{mg} \mathrm{L}^{-1}\right)$, peonidin 3-glucoside $(9.33 \mathrm{mg} /$ $\mathrm{L})$, cyanidin 3,5-diglucoside $(7.82 \mathrm{mg} / \mathrm{L})$, cyanidin 3-glucoside $(5.6 \mathrm{mg}$ $\left.\mathrm{L}^{-1}\right)$ and pelargonidin 3 -glucoside $\left(2.23 \mathrm{mg} \mathrm{L}^{-1}\right)$. The concentration process resulted in an increase of amounts of almost all anthocyanins, except for the degraded pelargonidin 3-glucoside. The mean values
Fig. 2. Average values of "foxy" aromas in the whole, concentrated, and reconstituted grape juices from SFV, Brazil. Legend: MA = methyl anthranilate, $\mathrm{AAP}=2$-aminoacetophenone and FUR $=$ furaneol. Means in the bars followed by the same letters among samples are not different according to the Tukeýs test at $1 \%$ of error probability.
Objects Labeled by Juices Component Loadings (adjusted to scale of objects)
Fig. 3. Principal components analysis. $\mathrm{WGJ}=$ whole grape juice, CGJ = concentrated grape juice and RGJ = reconstituted grape juice. Legend: Ga-Gallic acid; tCa-trans Caftaric acid; Syr-Syringic acid; ChlChlorogenic acid; cRe- cis-resveratrol; EgGEpigallocatechin gallate; PA2-Procyanidin A2; PB1Procyanidin B1; PB2-Procyanidin B2; Que-Quercetin 3-glucoside; Hes-Hesperidin; Nar-Naringenin; MalMalic acid; FUR-Furaneol; Tar-Tartaric acid; MatMaltose. obtained for the three main anthocyanins quantified in the concentrated juice were malvidin 3,5-diglucoside $\left(433.3 \mathrm{mg} \mathrm{kg}^{-1}\right.$ ), petunidin 3-glucoside (346 $\mathrm{mg} \mathrm{kg} \mathrm{kg}^{-1}$ ) and malvidin 3-glucoside (200.7 $\mathrm{mg} \mathrm{kg}^{-1}$ ). There was no significant difference according to the Tukey test between WGJ and RGJ juices regarding the most quantified anthocyanins, showing that the concentration process preserved most of these important pigments which are related to juice color. These results corroborate with the juice color analyzes, in which no significant differences where observed between whole and concentrated juices.

In a study performed by Capanoglu et al. (2013), a large loss in the content of anthocinins malvidin 3-glucoside, petunidin 3-glucoside, peonidin 3-glucoside, delphinidin 3-glucoside and of the flavonol quercetin 3-rutinoside (rutin) was reported in the conventional process of Nevsehir Patlak grape juice concentration up to $72{ }^{\circ} \mathrm{Brix}$; however, the process conditions such as evaporation temperature, vacuum 
Table 3

Component loadgins and model sumary of PCA.

\begin{tabular}{|c|c|c|}
\hline \multirow[t]{2}{*}{ Variables $^{\mathrm{a}}$} & \multicolumn{2}{|c|}{ Principal Component } \\
\hline & 1 & 2 \\
\hline \multicolumn{3}{|l|}{ Phenolic acids } \\
\hline Gallic acid & -0.58 & 0.814 \\
\hline Syringic acid & -0.58 & 0.814 \\
\hline Chlorogenic acid & 0.413 & 0.910 \\
\hline Caffeic acid & -0.58 & 0.814 \\
\hline Coumaric acid & -0.58 & 0.814 \\
\hline trans-Caftaric acid & 0.438 & 0.898 \\
\hline \multicolumn{3}{|l|}{ Favanols } \\
\hline Catechin & 0.994 & 0.101 \\
\hline Epicatechin & -0.58 & 0.814 \\
\hline Epigallocatechin & -0.58 & 0.814 \\
\hline Epigallocatechin gallate & -0.58 & 0.814 \\
\hline Procyanidin B1 & 0.889 & 0.458 \\
\hline Procyanidin B2 & 0.994 & 0.101 \\
\hline Procyanidin A2 & 0.995 & 0.096 \\
\hline \multicolumn{3}{|l|}{ Flavonols } \\
\hline Myricetin & 0.995 & 0.096 \\
\hline Quercetin 3-glucosdie & 0.80 & 0.424 \\
\hline Rutin & 0.99 & 0.032 \\
\hline Kaempferol 3-glucoside & 0.995 & 0.096 \\
\hline \multicolumn{3}{|l|}{ Anthocyanins } \\
\hline Cyanidin 3,5-Diglucoside & 0.995 & 0.096 \\
\hline Delphinidin 3-glucoside & 0.995 & 0.092 \\
\hline Malvidin 3,5-Diglucoside & 0.995 & 0.096 \\
\hline Cyaanidin 3- glucoside & 0.995 & 0.096 \\
\hline Pelargonidin 3-glucoside & -0.58 & 0.814 \\
\hline Peonidin 3-glucosdie & 0.995 & 0.096 \\
\hline Malvidin 3-glucoside & 0.995 & 0.096 \\
\hline Flavanones & 0.995 & 0.096 \\
\hline Naringenin & 0.581 & 0.616 \\
\hline Hesperidin & -0.58 & 0.814 \\
\hline \multicolumn{3}{|l|}{ Stilbenes } \\
\hline trans-Resveratrol & 0.978 & 0.147 \\
\hline cis-Resvertrol & 0.995 & 0.096 \\
\hline \multicolumn{3}{|l|}{ Antioxidant activity } \\
\hline DPPH & 0.995 & 0.096 \\
\hline ABTS & 0.995 & 0.096 \\
\hline $\mathrm{H} 2 \mathrm{O} 2$ & 0.995 & 0.096 \\
\hline FRAP & 0.995 & 0.096 \\
\hline \multicolumn{3}{|l|}{ "Foxy" aromatic compounds } \\
\hline 2-Aminoacetophenone & 0.995 & 0.096 \\
\hline Furaneol & 0.407 & 0.912 \\
\hline \multicolumn{3}{|l|}{ Organic acids } \\
\hline Citric & 0.954 & 0.21 \\
\hline Tartaric & 0.129 & 0.957 \\
\hline Malic & 0.905 & -0.371 \\
\hline Succinic & 0.995 & 0.096 \\
\hline Formic & 0.951 & 0.173 \\
\hline \multicolumn{3}{|l|}{ Oligossacharide } \\
\hline 1-Kestose & 0.975 & 0.150 \\
\hline \multicolumn{3}{|l|}{ Sugars } \\
\hline Maltose & 0.905 & -0.371 \\
\hline Fructose & 0.995 & 0.096 \\
\hline Glucose & 0.995 & 0.096 \\
\hline Grape juices $^{\text {b }}$ & 0.029 & -0.997 \\
\hline \multicolumn{3}{|l|}{ Model Summary } \\
\hline Total Eigenvalue & 31.51 & 10.68 \\
\hline$\%$ of Variance & 73.3 & 24.8 \\
\hline
\end{tabular}

${ }^{a}$ Principal Variable Normalization. ${ }^{\mathrm{b}}$ Supplementary variable.

pressure and number of tanks were not mentioned.

\subsubsection{Stilbenes and flavanones}

cis-resveratrol amounts were observed in average values of $8.32 \mathrm{mg}$ $\mathrm{L}^{-1}$ in whole juice, $57.7 \mathrm{mg} \mathrm{kg}^{-1}$ in concentrated juice and $5.63 \mathrm{mg} \mathrm{L}^{-1}$ in reconstituted juice. Furthermore, values of $1.17 \mathrm{mg} \mathrm{L}^{-1}$ in WGJ, $3.5 \mathrm{mg} \mathrm{kg}^{-1}$ in CGJ and $0.73 \mathrm{mg} \mathrm{L}^{-1}$ in RGJ were observed for transresveratrol (Table 2).

Regarding the stilbenes content, the whole and reconstituted juices did not present signifficant differences $(\mathrm{p}<0.01)$, indicating that these compounds were not degraded during the conservation process.

For flavanones, naringenin values of $3.53 \mathrm{mg} \mathrm{L}^{-1}, 5.17 \mathrm{mg} \mathrm{kg}^{-1}$ and $2.01 \mathrm{mg} \mathrm{L}^{-1}$ were found in the WGJ, CGJ and RGJ samples, respectively. Hesperidin was only present in the whole grape juice sample with mean values of $2.63 \mathrm{mg} \mathrm{L}^{-1}$. The WGJ and RGJ juices did not differ significantly in relation to naringenin, indicating that this compound was resistant to the concentration process. Hesperidin was lost in the concentration of grape juice.

\subsubsection{Phenolic acids}

Among the six quantified phenolic acids presented in Table 2, transcaftaric acid was the main compound present in grape juices, with average values of $397.08 \mathrm{mg} \mathrm{L}^{-1}$ (WGJ), $764.86 \mathrm{mg} \mathrm{kg}^{-1}$ (CGJ) and $159.14 \mathrm{mg} \mathrm{L}^{-1}$ (RGJ). The second main acid observed by amount was chlorogenic acid with values of $34.97 \mathrm{mg} \mathrm{L}^{-1}$ in WGJ, $38.28 \mathrm{mg} \mathrm{kg}^{-1}$ in CGJ and $8.44 \mathrm{mg} \mathrm{L}^{-1}$ in RGJ. A significant decrease of approximately $59.9 \%$ for trans- caftaric acid and $75.9 \%$ for chlorogenic acid in whole juice for reconstituted juice was observed according to the Tukey test.

Gallic, syringic, caffeic and p-coumaric acids were only present in the whole juice samples in values of $11.51,17.51$ and $10.15 \mathrm{mg} \mathrm{L}^{-1}$, respectively, demonstrating that these were degraded during the concentration process. The obtained results suggest that the concentration process considerably decreases the phenolic acid content of grape juices, with this phenolic family being the most susceptible to losses in the concentration process among those evaluated in the present study.

In the work of Guler et al. (2018), a great loss of gallic, caffeic, pcoumaric, vanillic and caftaric acids was also observed in the grape juice concentration process up to $45^{\circ} \mathrm{Brix}$ at a temperature of $50{ }^{\circ} \mathrm{C}$ in a vacuum of $600 \mathrm{~mm} \mathrm{Hg}$, in accordance with the results observed in the present study.

The values obtained for the families of phenolic compounds analyzed in the WGJ, CGJ and RGJ juices generally suggest that the decreasing order of compound loss during juice concentration was: Phenolic acids $>$ flavanols $>$ stilbenes $>$ anthocyanins $>$ flavanones $>$ flavonols.

\subsection{5. 'In vitro' antioxidant capacity}

According to Granato et al. (2018a), it is necessary to use methods which simulate different action mechanisms in evaluating the bioactivity of food and beverages through in vitro antioxidant capacity such as single electron transfer, transition metal chelating capacity and protein transfer hydrogen atoms, and associate these methods to obtain the profile of bioactive compounds such as phenolic compounds by instrumental techniques.

The antioxidant capacity (AOX) in the present study was measured in grape juices by the free radical scavenging with DPPH and ABTS methods, elimination of the reactive oxygen species by hydrogen peroxide $\left(\mathrm{H}_{2} \mathrm{O}_{2}\right)$, and the FRAP iron reducing power method; in addition, 29 antioxidant phenolic compounds were quantified by HPLC. The results for DPPH, ABTS and $\mathrm{H}_{2} \mathrm{O}_{2}$ methods were expressed as equivalent to millimols of Trolox per liter of juice ( $\mathrm{mmol} \mathrm{TE}^{-1}$ ), and the results for the FRAP method were expressed as equivalent to millimols of iron per liter $\left(\mathrm{mmol} \mathrm{Fe}{ }^{2+} \mathrm{L}^{-1}\right)$.

The AOX results are presented in Fig. 1. The mean of the AOX values for the whole grape juice was $21 \mathrm{mmol} \mathrm{TE} \mathrm{L}^{-1}, 28.7 \mathrm{mmol} \mathrm{TE} \mathrm{L}^{-1}$ and $122 \mathrm{mmol} \mathrm{TE} \mathrm{L}^{-1}$, for the DPPH, ABTS and $\mathrm{H}_{2} \mathrm{O}_{2}$ methods, respectively, and $71.3 \mathrm{mmol} \mathrm{Fe}^{2+} \mathrm{L}^{-1}$ for the FRAP method. Furthermore, the observed means for AOX for the reconstituted juice were $19.7 \mathrm{mmol} \mathrm{TE} \mathrm{L}^{-1}$ (DPPH), $26.3 \mathrm{mmol} \mathrm{TE} \mathrm{L}{ }^{-1}$ (ABTS), $107.7 \mathrm{mmol} \mathrm{TE} \mathrm{\textrm {L } ^ { - 1 }}\left(\mathrm{H}_{2} \mathrm{O}_{2}\right)$ and $57.7 \mathrm{mmol} \mathrm{Fe}^{2+} \mathrm{L}^{-1}$ (FRAP). No signifficant differences was observed in comparing the IGJ and RGJ juices according to the Tukey test ( $\mathrm{p}<0.01$ ), showing that the concentration process preserved the juice antioxidants after its reconstitution. Concentrated juice presented mean AOX values of $65 \mathrm{mmol} \mathrm{TE} \mathrm{L}^{-1}$ (DPPH), $86.7 \mathrm{mmol} \mathrm{TE} \mathrm{L}^{-1}$ (ABTS), $446.7 \mathrm{mmol} \mathrm{TE} \mathrm{L}^{-1}$ (H2O2) and $190.5 \mathrm{mmol} \mathrm{Fe}^{2+} \mathrm{L}^{-1}$ (FRAP), demonstrating that the concentration process significantly increased the AOX 
of this product.

The results observed for whole and reconstituted grape juices are in accordance with those reported in other studies for SFV whole juices (Lima et al., 2014; Dutra et al., 2018a; Padilha et al., 2017, 2019), with these AOX values being considered high.

In studies carried out by Muselík, García-alonso, Martín-lópez, and Žemli (2007), Tabart, Kevers, Pincemail, Defraigne, and Dommes (2009) and Mudnic et al. (2010), the antioxidant capacity of several individual phenolic compounds were measured by DPPH, ABTS, and FRAP methods, among others. It was observed that almost all flavanoids, flavonols, anthocyanins, flavanones and phenolic acids characterized in the present study showed antioxidant capacity in the DPPH, ABTS and FRAP systems. Based on this, the maintenance of most phenolic compounds in grape juice during concentration explains the maintenance of AOX in RGJ juices when compared to the WGJ juice.

Capanoglu et al. (2013) evaluated losses of phenolic compounds with an emphasis on anthocyanins, and antioxidant capacity by the DPPH, ABTS, FRAP and CUPRAC methods during the production stages of concentrated grape juice. When comparing the whole juice with the concentrate, a sharp decrease in AOX activity was observed followed by a reduction in phenolic contents, which demonstrates the effective contribution of phenolics in the AOX of grape juices.

\subsection{Aromatic "Foxy" compounds}

The results obtained for the quantified aromatic compounds are shown in Fig. 2. The "Foxy" Furaneol and 2-aminoacetophenone aromas were detected in all evaluated juices. Methyl anthranilate was not detected.

The average values of furaneol observed in the studied grape juices were $9.06,6.39$ and $1.93 \mathrm{mg} / \mathrm{L}$ for the whole, concentrated and reconstituted juices, respectively. 2-Aminoacetophenone was observed in amounts of $0.16,0.61$ and $0.20 \mathrm{mg} / \mathrm{L}$ in the WGJ, CGJ and RGJ samples, respectively. There was a significant decrease in furaneol content during the concentration process in which the values dropped from $9.06 \mathrm{mg} / \mathrm{L}$ in the WGJ to 1.93 in the RGJ, resulting in a decrease of $78.7 \%$ for this compound. The 2-aminoacetophenone remained stable in the concentration process, while the WGJ and RGJ juices did not differ significantly.

According to Dutra et al. (2018b), furaneol is an aromatic compound related to the typical juices from the SFV region, and its sensory perception threshold is $300 \mu \mathrm{g} \mathrm{L}^{-1}$, being associated with strawberry, pineapple and mango (Dutra et al., 2018b). 2-aminoacetophenone is a molecule formed by oxidative degradation of indolylacetic acid (IAA), a phytohormone which naturally occurs in grapes, and has a sensory perception threshold of $2 \mu \mathrm{g} \mathrm{L}{ }^{-1}$; being described as a fruity and sweet aroma (Hoenicke, Borchert, \& Grüning, K., Simat, T., 2002). Commercial SFV whole juices and samples of Brazilian commercial nectars (beverages obtained by reconstituting concentrated juices) were characterized in the study by Dutra et al. (2018b), in which the furaneol levels ranged from 0.45 to $2.08 \mathrm{mg} \mathrm{L}^{-1}$ (sugar added juices) and $0.15-7.83 \mathrm{mg} \mathrm{L}^{-1}$ (whole juices), depending on the grape variety used in the juice formulation.

Aguiar et al. (2012) pointed out that the aroma loss during conventional concentration is due to the high temperatures used. The same authors also reported a significant loss of volatile compounds associated with the aroma during the concentrating process of apple juices by reverse osmosis $\left(25^{\circ} \mathrm{C}\right.$ to $\left.28{ }^{\circ} \mathrm{Brix}\right)$ and osmotic evaporation $\left(30^{\circ} \mathrm{C}\right.$ to 51 $\left.{ }^{\circ} \mathrm{Brix}\right)$ at low temperatures. These data suggest that there will always be aromatic compound losses in any water removing process in juices, either by thermal degradation, water vapor drag, volatilization, or solubilization in mechanically removed water, to a greater or lesser extent.

Even with the furaneol loss during the concentration process $\left(50{ }^{\circ} \mathrm{C}\right.$, vacuum $>680 \mathrm{~mm} \mathrm{Hg}$, up to $68^{\circ}$ Brix) in the present study, the amount of this aromatic compound in RGJ juice was still six times greater than its threshold for sensory perception.

The results obtained in this study demonstrate that the concentration process resulted in a decrease of aroma compound content in the evaluated grape juices, but maintained a sufficient quantity of 'foxy' aromatic compounds to be sensorially detected.

\subsection{Principal component analysis}

A chemometric analysis was carried out using a principal component analysis (PCA) in order to evaluate the impact of processes on organic acids, sugars, phenolic compounds, flavors and antioxidant capacity of grape juices in an integrated manner. Principal components 1 and 2, PC1 and PC2 respectively, explained $98.1 \%$ of the experiment variance. PC1 explained $73.3 \%$ of the variance and PC2 $24.8 \%$, as can be seen in Fig. 3. Aiming at robustness in the interpretation, we only considered separations with an analysis factor (component loadgins) of $\geq 0.70$ in $\mathrm{PC}>0$, and $\leq-0.70$ at $\mathrm{PC}<0$, according to the results shown in Table 3.

With a higher percentage of explained variance, PC1 $>0$ separated CGJ due to higher values of sugars, organic acids, oligosaccharide 1kestose, 2-Aminoacetophenone, antioxidant capacity (DPPH, ABTS, FRAP and $\mathrm{H}_{2} \mathrm{O}_{2}$ ), stilbenes, anthocyanins and flavonols, catechin and procyanidins. These results demonstrate that the water reduction in the concentration process considerably increased the amount of all these metabolites and antioxidants in the CGJ.

PC2 clearly separated the samples from WGJ and RGJ, where PC2 $>0$ grouped the WGJ due to the higher values of phenolic acids, and the flavanols epicatechin, epigallocatechin and epigallocatechin gallate, pelargonidin 3-glucoside, hesperidin, furaneol and tartaric acid. This arrangment demonstrated that these were the main compounds with reduction during juice concentration. PC2 $<0$ grouped the RCJ due to the lower values of the compounds grouped with the WGJ.

The principal component analysis clearly showed the effect of the concentration and reconstitution processes of grape juice when compared to the whole juice, in which the main phenolic compounds lost were phenolic acids, some flavanols, hesperidin and pelargonidin 3glucoside. Other compounds lost in the concentration/reconstitution of juices were the aromatic compound furaneol and tartaric acid. However, the recostituted juice generally preserved the catechin and procyanidins flavanols, flavonols, anthocyanins, antioxidant capacity, the aromatic compound 2-Aminoacetophenone, prebitico1-kestose, sugars and organic acids.

PCA proved to be a powerful technique for interpreting the phenomena involved in the grape juice processes, in accordance with the Tukey test results of the present study. Other studies which also applied the PCA chemometric technique in interpreting the influence of processes on the quality of grape juice also showed agreement with multiple comparison tests such as Tukey, and also highlighted the power of PCA in interpreting the process phenomena (Granato, Koot, Schnitzler, \& van Ruth, 2015; Lima, M.d.S., Dutra, M.C.P., Toaldo, I.M., Corrêa, L.C., Pereira, G.E., De Oliveira, D., Bordignon-Luiz, M.T., Ninow, J.L., 2015; Coelho et al., 2018; Granato et al., 2018b; Silva et al., 2019; Padilha et al., 2019).

\section{Conclusion}

The grape juice concentration and reconstitution processes did not affect the basic analytical characteristics such as ${ }^{\circ}$ Brix, titratable acidity and color in comparison with the whole juice. However, the concentration and reconstitution process resulted in partial losses of caftaric-acid (59.9\%), chlorogenic-acid (75.9\%), aromatic compound furaneol $(78.7 \%)$ and tartaric-acid (88.1\%) compounds, and total losses (100\%) for gallic-acid, caffeic-acid, p-coumaric-acid, syringic-acid, hesperidin, pelargonidin-3-glucoside and epicatechins. Despite the losses in the furaneol aromatic compound, its concentration in the reconstituted juice was still 6 times greater than its sensory perception 
threshold, showing that this "Foxy" aroma could still be sensorially detected. The concentration and reconstitution of the grape juice preserved the antioxidant capacity and most of the quantified compounds. The concentration process of whole grape juice in the present study preserved most of the plant metabolites of interest in the sensory quality and bioactive compounds of grape juices. The reconstituted juice was considered to be of good nutritional quality and demonstrates the great potential for high quality concentrated juices in the São Francisco Valley in northeastern Brazil.

\section{CRediT authorship contribution statement}

Maria da Conceição Prudêncio Dutra: Conceptualization, Investigation, Formal analysis. Arão Cardoso Viana: Formal analysis. Giuliano Elias Pereira: Resources, Methodology. Rita de Cássia Mirella Resende Nassur: Writing - original draft, Visualization. Marcos dos Santos Lima: Conceptualization, Methodology, Project administration.

\section{Declaration of Competing Interest}

The authors declare that they have no known competing financial interests or personal relationships that could have appeared to influence the work reported in this paper.

\section{Acknowledgments}

The authors thank the company Queiroz Galvão Agrícola LTDA for making their grape juice processing line available for this study.

\section{Appendix A. Supplementary data}

Supplementary data to this article can be found online at https:// doi.org/10.1016/j.foodchem.2020.128399.

\section{References}

Aguiar, I.B., Miranda, N.G.M., Gomes, F.S., Santos, M.C.S., Freitas, D de. G.C., Tonon, R. V., \& Cabral, L.M.C. (2012). Physicochemical and sensory properties of apple juice concentrated by reverse osmosis and osmotic evaporation. Innovative Food Science and Emerging Technologies, 16, 137-142. http://dx.doi.org/10.1016/j.ifset.2012.05. 003

Aider, M., \& Halleux, D. (2008). Production of concentrated cherry and apricot juices by cryoconcentration technology. LWT - Food Science and Technology, 41, 1768-1775. https://doi.org/10.1016/j.lwt.2008.02.008.

Brasil (2018). Instrução Normativa $n^{\circ} 14$, de 08 de fevereiro de 2018. Estabelece a complementação dos padrões de identidade e qualidade do vinho e derivados da uva e do vinho. Diário Oficial da República Federativa do Brasil, Ed. 47, Seção 1, p. 4-6.

Campos, P. R. F., Módenes, A. N., Espinoza-Quiñones, F. R., Trigueros, D. E. G., Barros, S. T. D., \& Pereira, N. C. (2016). Improvement on the concentrated grape juice physicochemical characteristics by an enzymatic treatment and Membrane Separation Processes. Anais da Academia Brasileira de Ciências, 88, 423-436. https://doi.org/10. 1590/0001-3765201620140136.

Capanoglu, E., Vos, R. C. H., Hall, R. D., Boyacioglu, D., \& Beekwilder, J. (2013). Changes in polyphenol content during production of grape juice concentrate. Food Chemistry, 139, 521-526. https://doi.org/10.1016/j.foodchem.2013.01.023.

Coelho, E. M., Da Silva Padilha, C. V., Miskinis, G. A., De Sá, A. G. B., Pereira, G. E., De Azevêdo, L. C., et al. (2018). Simultaneous analysis of sugars and organic acids in wine and grape juices by HPLC: Method validation and characterization of products from Northeast Brazil. Journal of Food Composition and Analysis, 66, 160-167. https:// doi.org/10.1016/j.jfca.2017.12.017.

Corredor, Z., Rodríguez-Ribera, L., Coll, E., Montañés, R., Diaz, J. M., Ballarin, J., et al. (2016). Unfermented grape juice reduce genomic damage on patienundergoing hemodialysis. Food and Chemical Toxicology, 92, 1-7. https://doi.org/10.1016/j.fct. 2016.03.016.

Couto, D. S., Cabral, L. M. C., Da Mata, V. M., Deliza, R., \& Freitas, D. G. C. (2011). Concentration of pineapple juice by reverse osmosis: Physicochemical characteristics and consumer acceptance. Food Science and Technology, 31, 905-910. https://doi. org/10.1590/S0101-20612011000400012.

Dutra, M. C. P., De Souza, J. F., Viana, A. C., De Oliveira, D., Pereira, G. E., \& dos Santos Lima, M. (2018b). Rapid determination of the aromatic compounds methyl-anthranilate, 2'-aminoacetophenone and furaneol by GC-MS: Method validation and characterization of grape derivatives. Food Research International, 107, 613-618. https:// doi.org/10.1016/j.foodres.2018.03.020.
Dutra, M. C. P., Rodrigues, L. L., Oliveira, D., Pereira, G. E., \& dos Santos Lima, M. (2018a). Integrated analyses of phenolic compounds and minerals of Brazilian organic and conventional grape juices and wines: Validation of a method for determination of $\mathrm{Cu}, \mathrm{Fe}$ and Mn. Food Chemistry, 269, 157-165. https://doi.org/10. 1016/j.foodchem.2018.07.014.

Gollück, A. P. B., Souza, J. C., \& Tavares, D. Q. (2008). Sensory stability of Concord and Isabel concentrated grape juices during storage. Journal of Sensory Studies, 23, 340-353. https://doi.org/10.1111/j.1745-459X.2008.00159.x.

Granato, D., de Magalhães Carrapeiro, M., Fogliano, V., \& van Ruth, S. M. (2016). Effects of geographical origin, varietal and farming system on the chemical composition and functional properties of purple grape juices: A review. Trends in Food Science and Technology, 52, 31-48. https://doi.org/10.1016/j.tifs.2016.03.013.

Granato, D., Koot, A., Schnitzler, E., \& van Ruth, S. M. (2015). Authentication of geographical origin and crop system of grape juices by phenolic compounds and antioxidant activity using chemometrics. Journal of Food Science, 80(3), C584-C593. https://doi.org/10.1111/1750-3841.12794.

Granato, D., Putnik, P., Kovacevíc, D. B., Santos, J. S., Calado, V., Rocha, R. S., et al. (2018). Trends in Chemometrics: Food Authentication, Microbiology, and Effects of Processing. Comprehensive Reviews in Food Science and Food Safety, 17, 663-677. https://doi.org/10.1111/1541-4337.12341.

Granato, D., Shahidi, F., Wrolstad, R., Kilmartin, P., Melton, L. D., Hidalgo, F. J., et al. (2018). Antioxidant activity, total phenolics and flavonoids contents: Should we ban in vitro screening methods? Food Chemistry, 264, 471-475. https://doi.org/10.1016/ j.foodchem.2018.04.012.

Guler, A., Tokusolgu, O., \& Artik, N. (2018). Alterations on phenolic compounds and antioxidant activity during sour grape juice concentrate processing. Ciência e Técnica Vitivinícola, 32, 136-144. https://doi.org/10.1051/ctv/20183302136.

Gunathilake, K. D. P. P., Yu, L. J., \& Rupasinghe, H. P. V. (2014). Reverse osmosis as a potential technique to improve antioxidant properties of fruit juices used for functional beverages. Food Chemistry, 148, 335-341. https://doi.org/10.1016/j. foodchem.2013.10.061.

Hoenicke, K., Borchert, O., \& Grüning, K., Simat, T. (2002). Untypical aging off-flavor in wine: Synthesis of potential degradation compounds of indole-3-acetic acid and kynurenine and their evaluation as precursors of 2-aminoacetophenone. Journal of Agricultural and Food Chemistry, 50, 4303-4309. https://doi.org/10.1021/jf011672r.

Kim, Y. K., Guo, Q., \& Packer, L. (2002). Free radical scavenging activity of red ginseng aqueous extracts. Toxicology, 172(2), 149-156. https://doi.org/10.1016/S0300-483X (01)00585-6.

Li, N., Wei, Y., Wang, J., Zhou, J., \& Wang, J. (2019). Optimization of deacidification for concentrated grape juice. Food Science \& Nutrition, 7, 2050-2058. https://doi.org/10 1002/fsn3.1037.

Lima, M.d.S., Dutra, M.C.P., Toaldo, I.M., Corrêa, L.C., Pereira, G.E., De Oliveira, D., Bordignon-Luiz, M.T., Ninow, J.L. (2015). Phenolic Compounds, Organic Acids and Antioxidant Activity of Grape Juices Produced in Industrial Scale by Different Processes of Maceration. Food Chemistry, 188, 384-392. http://dx.doi.org/10.1016/ j.foodchem.2015.04.014

Lima, M.d.S., Nunes, P.C., Silva, B.L.A., Padilha, C.V.S., Bonfim, T. H. F., Stamford, T.L. M., Vasconcelos, M.A.S., Aquino, J.S. (2019). Determining 1-kestose, nystose and raffinose oligosaccharides in grape juices and wines using HPLC: method validation and characterization of products from Northeast Brazil. Journal of Food Science and Technology, 56, 4575-4584. https://doi.org/10.1007/s13197-019-03936-x

Lima, M.d.S., Silani, I. S. V., Toaldo, I. M., Correa, L. C., Biasoto, A. C. T., Pereira, G. E., Ninow, J. L., Bordignon-Luiz, M. T. (2014). Phenolic compounds, organic acids and antioxidant activity of grape juices produced from new Brazilian varieties planted in the Northeast Region of Brazil. Food Chemistry, 161, 94-103. https://doi.org/10. 1016/j.foodchem.2014.03.109

Mello, L.M.R. (2019). Vitivinicultura brasileira: panorama 2018. Comunicado Técnico Embrapa, 210, 1-12. Available in: https://www.infoteca.cnptia.embrapa.br/infoteca/bitstream/doc/1117682/1/ComunicadoTecnico211.pdf

Mudnic, I., Modun, D., Rastija, V., Vukovic, J., Brizic, I., Katalinic, V., et al. (2010). Antioxidative and vasodilatory effects of phenolic acids in wine. Food Chemistry, 119, 1205-1210. https://doi.org/10.1016/j.foodchem.2009.08.038.

Muselík, J., García-alonso, M., Martín-lópez, M. P., \& Žemli, M. (2007). Measurement of Antioxidant Activity of Wine Catechins, Procyanidins, Anthocyanins and Pyranoanthocyanins. Internacional Journal of Molecular Sciences, 8, 797-809. https:// doi.org/10.3390/i8080797.

OIV - Organisation Internationale de la Vigne et du Vin (2011). Recueil des methods internationals d'analyse des vins et des mouts, edition 2011. 8th Assemblée Générale, 21 June 2010, Paris.

Padilha, C. V. S., dos Santos Lima, M., Toaldo, I. M., Pereira, G. E., \& Bordignon-Luiz, M. T. (2019). Effects of successive harvesting in the same year on quality and bioactive compounds of grapes and juices in semi-arid tropical viticulture. Food Chemistry, 301, Article 125170. https://doi.org/10.1016/j.foodchem.2019.125170.

Padilha, C. V. S., Miskinis, G. A., De Souza, M. E. A. O., Pereira, G. E., Oliveira, D., Bordignon-Luiz, M. T., et al. (2017). Rapid determination of flavonoids and phenolic acids in grape juices and wines by RP-HPLC/DAD: Method validation and characterization of commercial products of the new Brazilian varieties of grape. Food Chemistry, 228, 106-115. https://doi.org/10.1016/j.foodchem.2017.01.137.

Re, R., Pellegrini, N., Proteggente, A., Pannala, A., Yang, M., \& Rice-Evans, C. (1999). Antioxidant activity applying an improved ABTS radical cationdecolorization assay. Free Radical Biologyand Medicine, New York, 26, 1231-1237. https://doi.org/10. 1016/S0891-5849(98)00315-3.

Rojo, M. J., Cristiani, M., Szerman, N., Gonzalez, M. L., Lerena, M. C., Mercado, L. A., et al. (2019). Reduction of Zygosaccharomyces rouxii Population in Concentrated Grape Juices by Thermal Pasteurization and Hydrostatic High Pressure Processing. Food and Bioprocess Technology, 12, 781-788. https://doi.org/10.1007/s11947-019- 
02251-9.

Ruch, R. J., Cheng, S. J., \& Klaunig, J. E. (1989). Prevention of cytotoxicity and inhibition of intercellular communication by antioxidant catechins isolated from Chinese green tea. Carcinogenese, 10, 1003-1008. https://doi.org/10.1093/carcin/10.6.1003.

Rufino, M. D. S. M., Alves, R. E., de Brito, E. S., de Morais, S. M., Sampaio, C. D. G., PérezJiménez, J., \& Saura-Colixto, F. D. (2006). Metodologia científica: Determinação da atividade antioxidante total em frutas pelo método de redução do ferro (FRAP). Comunicado Técnico Embrapa, 125, 1-4. Available in: https://www.infoteca.cnptia. embrapa.br/infoteca/bitstream/doc/664093/1/cot126.pdf

Silva, G. G., Dutra, M. C. P., Oliveira, J. B., Rybka, A. C. P., Pereira, G. E., \& Lima, M.d.S. (2019). Processing methods with heat increases bioactive phenolic compounds and antioxidant activity in grape juices. Journal of Food Biochemistry, 43, Article e12732. https://doi.org/10.1111/jfbc.12732.
Tabart, J., Kevers, C., Pincemail, J., Defraigne, J.-O., \& Dommes, J. (2009). Comparative antioxidant capacities of phenolic compounds measured by various tests. Food Chemistry, 113, 1226-1233. https://doi.org/10.1016/j.foodchem.2008.08.013.

Toaldo, I. M., Cruz, F. A., Silva, E. L., \& Bordignon-Luiz, M. T. (2016). Acute consumption of organic and conventional tropical grape juices (V. labrusca L.) increases antioxidants in plasma and erythrocytes, but not glucose and uric acid levels, in healthy individuals. Nutrition Research, 36, 808-817. https://doi.org/10.1016/j.nutres.2016. 04.010.

Toscano, L. T., Silva, A. S., Toscano, L. T., Tavares, R. L., Biasoto, A. C. T., de Camargo, A. C., et al. (2017). Phenolics from purple grape juice increase serum antioxidant status and improve lipid profile and blood pressure in healthy adults under intense physical training. Journal of Funcional Foods, 33, 419-424. https://doi.org/10.1016/j.jff.2017. 03.063. 